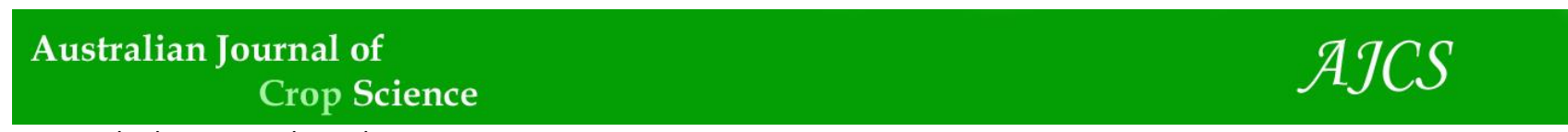

AJCS 11(04):453-458 (2017)

ISSN:1835-2707

doi: $10.21475 /$ ajcs.17.11.04.355

\title{
Attractiveness and non-preference of soybean cultivars to Heliothis virescens (Lepidoptera: Noctuidae) feeding
}

\section{André Cirilo de Sousa Almeida*, Franciele Cristina da Silva, Jean Aparecido Ferreira Davi Almeida, Flávio Gonçalves de Jesus}

\author{
Instituto Federal Goiano-Câmpus Urutaí, Rodovia Prof. Geraldo Silva Nascimento, 75790-000, Urutaí, GO, \\ Brazil
}

*Corresponding author: andre_cirillo@hotmail.com

\begin{abstract}
The tobacco budworm (Heliothis virescens) is a polyphagous species that damages soybean crops. In the search for sustainable pest control methods, the objective of this study was to evaluate $H$. virescens non-preference (antixenosis) of soybean cultivars by examining larval attraction and feeding responses to the nine cultivars. At 45 days after planting, the attraction and feeding tests were performed with third-instar larvae, and the number of larvae attracted to leaf disks, their leaf consumption, and an attractiveness index were determined in free-choice and no-choice tests. For the free-choice attractiveness test, arranged in a randomized block design with 10 replications were performed. For the no-choice attractiveness test, a completely randomized design with 20 replications was adopted. The cultivar NK $7059 \mathrm{RR}$ was the most attractive and consumed, showing susceptibility to H. virescens. The cultivars IAC 100 and M 7110 IPRO (Bt) showed non-preference-type resistance These latter cultivars can be used by soybean producers or plant breeders as donors of resistance genes in plant improvement programs for resistance to $\mathrm{H}$. virescens.
\end{abstract}

Received 30 Sep 2016; Revised 11 March 2017; Accepted 15 March 2017.

Keywords: Antixenosis, Insecta, arthropod-plant interaction, tobacco budworm, plant resistance to insects.

\section{Introduction}

The soybean, Glycine $\max (\mathrm{L}$.$) Merrill (Fabales: Fabaceae),$ is one of the main economically important crops in the world, and the largest soybean producers are the United States, Brazil, and Argentina, in that order (Castanheira and Freire, 2013; Souza et al., 2014a). One of the main factors causing production losses is pest damage (Bueno et al., 2011b; Hoffnann-Campo et al., 2012), including damage by defoliating caterpillars (Lourenção et al., 2010; Bueno et al., 2012). The tobacco budworm, Heliothis virescens (Fabricius 1781), is a defoliating caterpillar that damages soybean crops at all stages of crop development, feeding on pods and flower buds, promoting defoliation, and reducing the plant photosynthetic rate and consequently the crop yield (Tomquelski and Maruyama, 2009; Bueno et al. 2013; Owen et al., 2013). The main host of this pest is cotton (Gossypium hirsutum L.), but because of its polyphagous feeding behavior, this pest also feeds on tomato, sunflower, bean, and tobacco (Fitt, 1989; Pratissoli et al., 2006; Karpinski et al., 2014). This insect is a facultative migratory pest that can fly long distances in search of its host plants (Farrow and Daly, 1987). Inappropriate insecticide applications and their undesirable effects as well as the selection of individuals resistant not only to chemical insecticides but also to transgenic plants (Blanco et al., 2009; Sosa-Gomez and Silva, 2010; Bernardi et al., 2014; Bortolotto et al., 2014) lead to the need to investigate alternative pest control methods and strengthen integrated pest management (IPM) (Bueno et al., 2011a). Among the alternative methods, the exploitation of plant resistance to insects is considered ideal because this approach does not affect the environment, may be concomitantly used with other control methods, and does not require producers to deal with sophisticated technology (Smith, 2005; Seifi et al., 2013; Boiça Junior et al., 2015).

Several studies report the resistance of soybean genotypes to different insect pest species (Silva et al., 2012; 2013; 2014; Souza et al., 2014a; 2014b). Souza et al. (2012) concluded that the IAC 100 cultivar was highly resistant to Spodoptera eridania (Lepidoptera: Noctuidae). Silva et al. (2014) observed antixenosis-type resistance in soybean genotypes IAC 100 and IAC 19 to the stink bug Piezodorus guildinii (Hemiptera: Pentatomidae). Additionally, Souza et al. (2014a, b) observed antixenosis-type resistance in genotypes IAC 100 and IAC 17 to Euschistus heros (Hemiptera: Pentatomidae) and antibiosis in IAC 100 to Chrysodeixis includens (Lepidoptera: Noctuidae). Factors such as the presence of trichomes, food substrate color, and the release of volatile compounds cause plants to express antixenosis-type resistance (Smith, 2005). Souza et al. (2014b) and Silva et al. (2014) observed that soybean varieties with a greater number of trichomes showed less consumption by stink bugs. In view of the importance of $H$. virescens in soybean crops and the scarcity of information on not only the pest but also pest resistant varieties, the objective of this study was to evaluate antixenosis-type resistance in soybean cultivars to $H$. virescens.

\section{Results}

In the free-choice test, significant differences in attractiveness were observed among the soybean cultivars at $6,12$, and $24 \mathrm{~h}$ (Table 1$)$. At $6 \mathrm{~h}$, the most attractive cultivars $(p=0.0066)$ were NA 7337 RR, SYN 1163 RR, and NK 
Table 1. Mean number ( \pm SEM) of Heliothis virescens larvae (Lepidoptera: Noctuidae) on soybean leaf disks and dry disk weight consumed $(\mathrm{mg})$ in the free-choice test of different soybean cultivars. Urutaí, Goias, Brazil.

\begin{tabular}{|c|c|c|c|c|c|c|}
\hline \multirow[t]{2}{*}{ Cultivars } & \multicolumn{6}{|c|}{ Time in minutes ${ }^{1}$} \\
\hline & 1 & 3 & 5 & 10 & 15 & 30 \\
\hline P 98Y30 RR & $0.1 \pm 0.10$ & $0.2 \pm 0.13$ & $0.1 \pm 0.10$ & $0.1 \pm 0.10$ & $0.2 \pm 0.13$ & $0.1 \pm 0.10$ \\
\hline NA 7337 RR & $0.4 \pm 0.22$ & $0.0 \pm 0.00$ & $0.2 \pm 0.13$ & $0.7 \pm 0.30$ & $0.2 \pm 0.13$ & $0.3 \pm 0.15$ \\
\hline SYN 1163 RR & $0.4 \pm 0.16$ & $0.2 \pm 0.13$ & $0.3 \pm 0.21$ & $0.1 \pm 0.10$ & $0.1 \pm 0.10$ & $0.0 \pm 0.00$ \\
\hline NK 7059 RR & $0.2 \pm 0.13$ & $1.0 \pm 1.00$ & $0.1 \pm 0.10$ & $0.3 \pm 0.21$ & $0.3 \pm 0.21$ & $0.5 \pm 0.22$ \\
\hline ANTA 82 RR & $0.2 \pm 0.13$ & $0.2 \pm 0.13$ & $0.2 \pm 0.13$ & $0.2 \pm 0.13$ & $0.3 \pm 0.21$ & $0.5 \pm 0.22$ \\
\hline M 7110 IPRO & $0.1 \pm 0.10$ & $0.3 \pm 0.21$ & $0.3 \pm 0.15$ & $0.3 \pm 0.21$ & $0.1 \pm 0.10$ & $0.6 \pm 0.22$ \\
\hline BRS 8160 RR & $0.0 \pm 0.00$ & $0.2 \pm 0.13$ & $0.1 \pm 0.10$ & $0.4 \pm 0.16$ & $0.4 \pm 0.22$ & $0.3 \pm 0.15$ \\
\hline BRSGO Jataí & $0.0 \pm 0.00$ & $0.3 \pm 0.15$ & $0.0 \pm 0.00$ & $0.3 \pm 0.15$ & $0.2 \pm 0.13$ & $0.1 \pm 0.10$ \\
\hline IAC 100 & $0.2 \pm 0.13$ & $0.5 \pm 0.16$ & $0.2 \pm 0.13$ & $0.1 \pm 0.10$ & $0.5 \pm 0.22$ & $0.1 \pm 0.10$ \\
\hline$F_{8,9}$ & 1.31 & 0.62 & 0.60 & 1.22 & 0.59 & 1.74 \\
\hline$P$ & 0.2504 & 0.7574 & 0.7693 & 0.297 & 0.7828 & 0.1024 \\
\hline \multirow[t]{2}{*}{ Cultivars } & \multicolumn{5}{|c|}{ Time in hours } & Weight \\
\hline & 1 & 2 & 6 & 12 & 24 & consumed \\
\hline P 98Y30 RR & $0.1 \pm 0.10$ & $0.2 \pm 0.13$ & $0.1 \pm 0.10 \mathrm{~b}$ & $0.3 \pm 0.16 b$ & $0.1 \pm 0.10 \mathrm{~b}$ & $3.35 \pm 0.48 b$ \\
\hline NA 7337 RR & $0.1 \pm 0.10$ & $0.1 \pm 0.10$ & $0.7 \pm 0.15 a$ & $0.6 \pm 0.15 b$ & $0.7 \pm 0.21 \mathrm{a}$ & $4.16 \pm 0.86 \mathrm{~b}$ \\
\hline SYN 1163 RR & $0.1 \pm 0.10$ & $0.2 \pm 0.13$ & $0.6 \pm 0.16 \mathrm{a}$ & $0.6 \pm 0.22 b$ & $0.5 \pm 0.22 \mathrm{a}$ & $5.09 \pm 1.04 \mathrm{~b}$ \\
\hline NK 7059 RR & $0.2 \pm 0.13$ & $0.2 \pm 0.13$ & $0.9 \pm 0.24 \mathrm{a}$ & $1.2 \pm 0.22 \mathrm{a}$ & $0.7 \pm 0.15 a$ & $10.87 \pm 1.26 \mathrm{a}$ \\
\hline ANTA 82 RR & $0.2 \pm 0.20$ & $0.4 \pm 0.16$ & $0.4 \pm 0.10 \mathrm{~b}$ & $0.5 \pm 0.16 b$ & $0.5 \pm 0.16 \mathrm{a}$ & $4.69 \pm 0.86 b$ \\
\hline M 7110 IPRO & $0.4 \pm 0.16$ & $0.7 \pm 0.26$ & $0.4 \pm 0.26 b$ & $0.5 \pm 0.16 b$ & $0.2 \pm 0.13 b$ & $3.32 \pm 0.66 \mathrm{~b}$ \\
\hline BRS 8160 RR & $0.2 \pm 0.13$ & $0.2 \pm 0.13$ & $0.2 \pm 0.13 b$ & $0.2 \pm 0.10 \mathrm{~b}$ & $0.1 \pm 0.10 b$ & $2.58 \pm 0.35 b$ \\
\hline BRSGO Jataí & $0.0 \pm 0.00$ & $0.3 \pm 0.21$ & $0.1 \pm 0.10 \mathrm{~b}$ & $0.2 \pm 0.10 b$ & $0.2 \pm 0.13 b$ & $3.23 \pm 0.74 \mathrm{~b}$ \\
\hline IAC 100 & $0.3 \pm 0.15$ & $0.2 \pm 0.13$ & $0.0 \pm 0.00 \mathrm{~b}$ & $0.0 \pm 0.00 \mathrm{~b}$ & $0.1 \pm 0.00 \mathrm{~b}$ & $1.82 \pm 0.43 \mathrm{~b}$ \\
\hline$F_{8,9}$ & 0.85 & 1.21 & 2.94 & 4.47 & 2.97 & 11.67 \\
\hline$P$ & 0.559 & 0.3053 & 0.0066 & $<0.0001$ & 0.0061 & $<0.0001$ \\
\hline
\end{tabular}

${ }^{\mathrm{T}}$ Means followed by the same letter do not differ significantly according to the Scott-Knott test at the 5\% probability level. SEM = standard error of the mean.

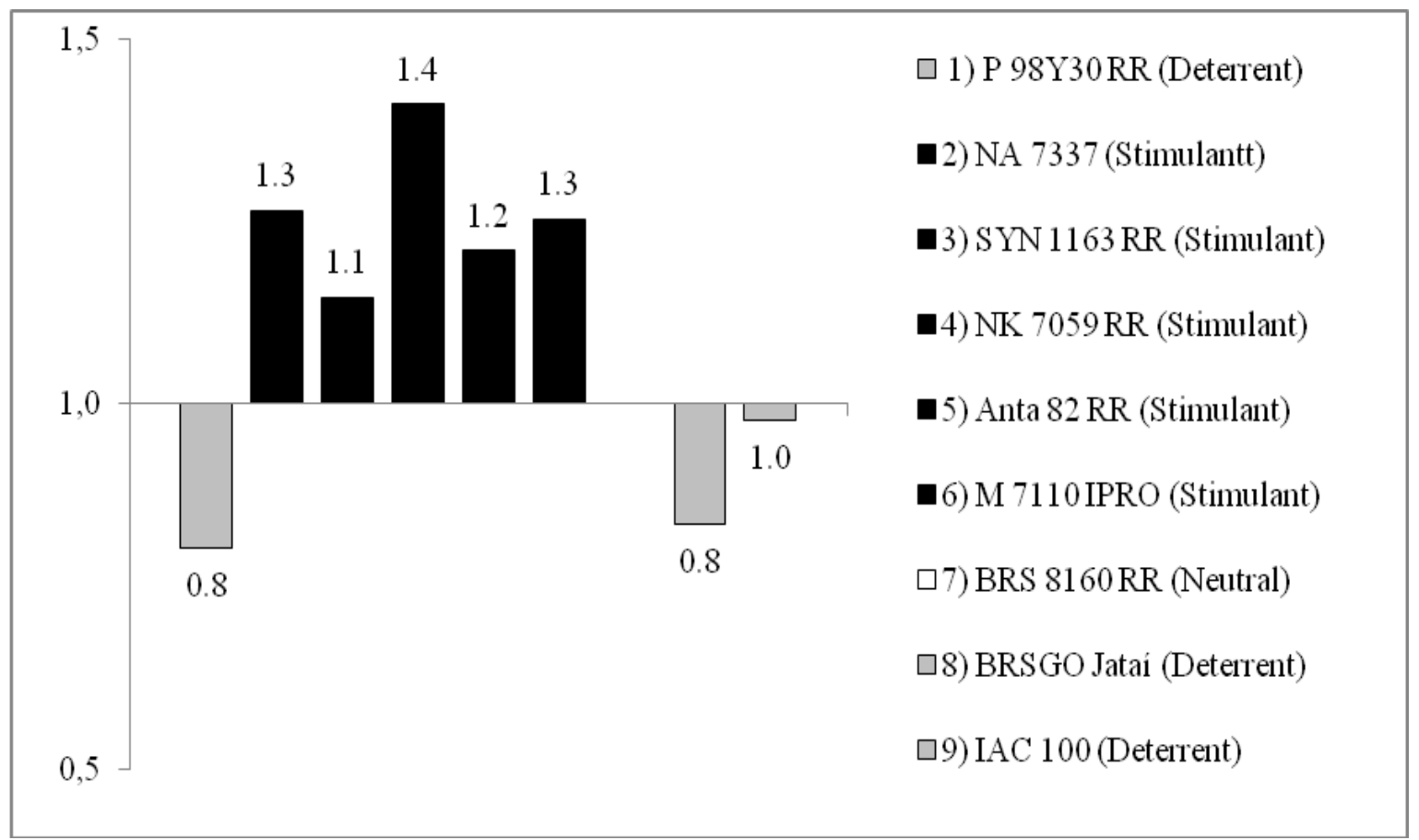

Fig 1. Attractiveness index (AI) of Heliothis virescens larvae (Lepidoptera: Noctuidae) for leaf disks of soybean cultivars in the freechoice test. Urutaí, Goias, Brazil. 
Table 2. Mean number ( \pm SEM) of Heliothis virescens larvae (Lepidoptera: Noctuidae) on soybean leaf disks and dry disk weight consumed $(\mathrm{mg})$ in the no-choice test of different soybean cultivars. Urutaí, Goias, Brazil.

\begin{tabular}{|c|c|c|c|c|c|c|}
\hline \multirow[t]{2}{*}{ Cultivars } & \multicolumn{6}{|c|}{ Time in minutes ${ }^{1}$} \\
\hline & 1 & 3 & 5 & 10 & 15 & 30 \\
\hline P 98Y30 RR & $0.05 \pm 0.05$ & $0.05 \pm 0.05$ & $0.00 \pm 0.00 \mathrm{~b}$ & $0.10 \pm 0.06 \mathrm{~b}$ & $0.10 \pm 0.06 \mathrm{~b}$ & $0.00 \pm 0.00 \mathrm{~b}$ \\
\hline NA 7337 RR & $0.00 \pm 0.00$ & $0.05 \pm 0.05$ & $0.05 \pm 0.05 b$ & $0.00 \pm 0.00 \mathrm{~b}$ & $0.20 \pm 0.09 \mathrm{~b}$ & $0.10 \pm 0.06 \mathrm{~b}$ \\
\hline SYN 1163 RR & $0.05 \pm 0.05$ & $0.05 \pm 0.05$ & $0.00 \pm 0.00 \mathrm{~b}$ & $0.00 \pm 0.00 \mathrm{~b}$ & $0.10 \pm 0.06 \mathrm{~b}$ & $0.00 \pm 0.00 \mathrm{~b}$ \\
\hline NK 7059 RR & $0.15 \pm 0.08$ & $0.30 \pm 0.10$ & $0.35 \pm 0.10 \mathrm{a}$ & $0.35 \pm 0.10 \mathrm{a}$ & $0.45 \pm 0.11 \mathrm{a}$ & $0.40 \pm 0.11 \mathrm{a}$ \\
\hline ANTA 82 RR & $0.10 \pm 0.06$ & $0.10 \pm 0.06$ & $0.00 \pm 0.00 \mathrm{~b}$ & $0.05 \pm 0.05 b$ & $0.10 \pm 0.06 b$ & $0.15 \pm 0.08 b$ \\
\hline M 7110 IPRO & $0.55 \pm 0.49$ & $0.10 \pm 0.06$ & $0.05 \pm 0.05 b$ & $0.05 \pm 0.05 b$ & $0.25 \pm 0.09 \mathrm{a}$ & $0.30 \pm 0.10 \mathrm{a}$ \\
\hline BRS 8160 RR & $0.30 \pm 0.10$ & $0.20 \pm 0.09$ & $0.25 \pm 0.09 \mathrm{a}$ & $0.20 \pm 0.09 \mathrm{a}$ & $0.30 \pm 0.10 \mathrm{a}$ & $0.15 \pm 0.08 b$ \\
\hline BRSGO Jataí & $0.10 \pm 0.08$ & $0.05 \pm 0.05$ & $0.05 \pm 0.05 \mathrm{~b}$ & $0.05 \pm 0.05 b$ & $0.00 \pm 0.00 \mathrm{~b}$ & $0.05 \pm 0.05 b$ \\
\hline IAC 100 & $0.10 \pm 0.06$ & $0.10 \pm 0.06$ & $0.10 \pm 0.05 \mathrm{~b}$ & $0.05 \pm 0.05 \mathrm{~b}$ & $0.10 \pm 0.06 \mathrm{~b}$ & $0.05 \pm 0.05 b$ \\
\hline$F_{8,19}$ & 0.91 & 1.51 & 4.03 & 3.27 & 2.76 & 3.60 \\
\hline$P$ & 0.5089 & 0.1546 & 0.0002 & 0.0017 & 0.0068 & 0.0007 \\
\hline \multirow[t]{2}{*}{ Cultivars } & \multicolumn{5}{|c|}{ Time in hours } & Weight \\
\hline & 1 & 2 & 6 & 12 & 24 & consumed \\
\hline P 98Y30 RR & $0.20 \pm 0.09 b$ & $0.10 \pm 0.00 \mathrm{~b}$ & $0.45 \pm 0.11 b$ & $0.55 \pm 0.11 b$ & $0.80 \pm 0.09 \mathrm{a}$ & $3.62 \pm 0.91 \mathrm{a}$ \\
\hline NA 7337 RR & $0.30 \pm 0.10 \mathrm{a}$ & $0.30 \pm 0.10 \mathrm{a}$ & $0.55 \pm 0.11 \mathrm{a}$ & $0.55 \pm 0.11 b$ & $0.70 \pm 0.10 \mathrm{a}$ & $3.95 \pm 0.66 \mathrm{a}$ \\
\hline SYN 1163 RR & $0.00 \pm 0.00 \mathrm{~b}$ & $0.05 \pm 0.05 b$ & $0.35 \pm 0.10 \mathrm{~b}$ & $0.30 \pm 0.10 \mathrm{c}$ & $0.65 \pm 0.10 \mathrm{a}$ & $2.59 \pm 0.59 b$ \\
\hline NK 7059 RR & $0.40 \pm 0.11 \mathrm{a}$ & $0.40 \pm 0.11 \mathrm{a}$ & $0.80 \pm 0.09 \mathrm{a}$ & $1.00 \pm 0.00 \mathrm{a}$ & $0.90 \pm 0.06 \mathrm{a}$ & $3.50 \pm 0.41 \mathrm{a}$ \\
\hline ANTA 82 RR & $0.35 \pm 0.10 \mathrm{a}$ & $0.20 \pm 0.09 a$ & $0.60 \pm 0.11 \mathrm{a}$ & $0.65 \pm 0.10 \mathrm{~b}$ & $0.60 \pm 0.11 \mathrm{a}$ & $1.97 \pm 0.34 b$ \\
\hline M 7110 IPRO & $0.40 \pm 0.11 \mathrm{a}$ & $0.35 \pm 0.10 \mathrm{a}$ & $0.25 \pm 0.09 b$ & $0.20 \pm 0.09 \mathrm{c}$ & $0.10 \pm 0.06 \mathrm{~b}$ & $0.58 \pm 0.17 b$ \\
\hline BRS 8160 RR & $0.30 \pm 0.10 \mathrm{a}$ & $0.30 \pm 0.10 \mathrm{a}$ & $0.65 \pm 0.10 \mathrm{a}$ & $0.60 \pm 0.11 b$ & $0.35 \pm 0.10 \mathrm{~b}$ & $2.66 \pm 0.60 \mathrm{~b}$ \\
\hline BRSGO Jataí & $0.15 \pm 0.08 b$ & $0.00 \pm 0.00 \mathrm{~b}$ & $0.60 \pm 0.11 \mathrm{a}$ & $0.50 \pm 0.11 b$ & $0.25 \pm 0.09 \mathrm{~b}$ & $2.07 \pm 0.54 b$ \\
\hline IAC 100 & $0.10 \pm 0.06 \mathrm{~b}$ & $0.00 \pm 0.00 \mathrm{~b}$ & $0.15 \pm 0.08 \mathrm{~b}$ & $0.15 \pm 0.08 \mathrm{c}$ & $0.50 \pm 0.11 \mathrm{a}$ & $1.85 \pm 0.50 \mathrm{~b}$ \\
\hline$F_{8,19}$ & 2.23 & 3.49 & 3.85 & 6.75 & 7.03 & 3.49 \\
\hline$P$ & 0.0273 & 0.0009 & 0.0003 & $<0.0001$ & $<0.0001$ & 0.0019 \\
\hline
\end{tabular}

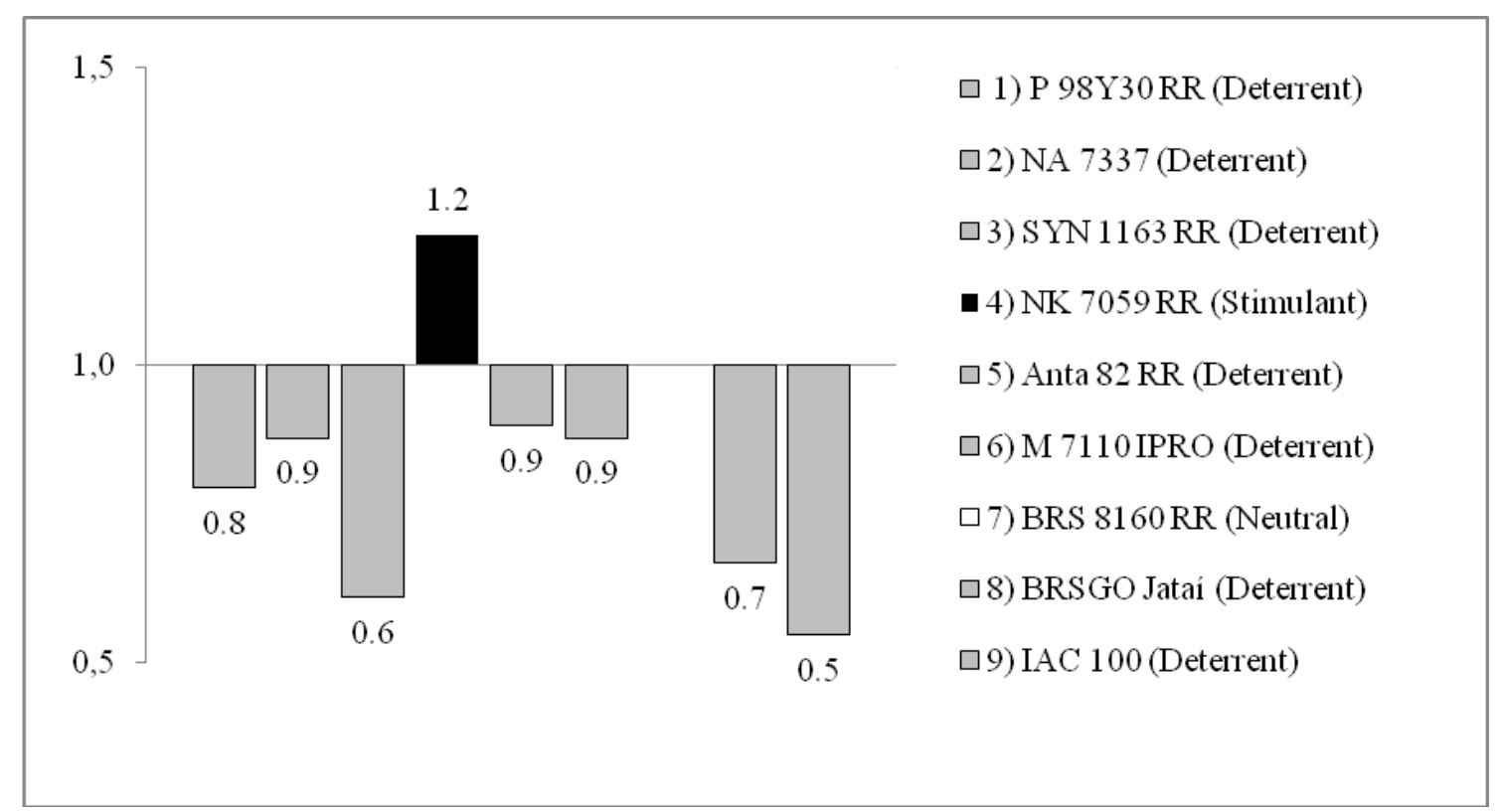

Fig 2. Attractiveness index (AI) of Heliothis virescens larvae (Lepidoptera: Noctuidae) for leaf disks of soybean cultivars in the nochoice test. Urutaí, Goias, Brazil.

7059 RR, with mean larval counts of $0.7,0.6$, and 0.9 , respectively. These means were higher than those of the other cultivars, which ranged from 0.0 (IAC 100) to 0.4 (ANTA 82 and M 7110 IPRO). After $12 \mathrm{~h}$ of evaluation, the cultivar that presented the highest mean attractiveness $(p<0.0001)$ was NK 7059 RR (1.2 larvae), differing from the others, which ranged from 0.0 (IAC 100) to 0.6 (NA 7337 RR and SYN $1163 \mathrm{RR})$. At $24 \mathrm{~h}$, the cultivars with the highest attractiveness $(p=0.0061)$ were NA 7337 RR and NK 7059 RR (0.7 larvae) as well as SYN 1163 RR and ANTA 82 RR
(0.5 larvae). Regarding the dry weight consumed in the freechoice test, the most heavily consumed cultivar $(p<0.0001)$ was NK 7059 RR (10.87 mg), the consumption of which differed from that of the more lightly consumed cultivars, except that of IAC 100 (1.82 mg).

Based on these AIs, the cultivars NA 7337 RR, SYN 1163 RR, NK 7059 RR, ANTA 82 RR, and M 7110 IPRO stimulated $H$. virescens in the free-choice test. By contrast, the cultivars P 98 Y30 RR, BRSGO Jataí, and IAC 100 acted as deterrents (Figure 1). 
In the no-choice test, significant differences in the mean number of larvae that fed on the leaf disks occurred at all the observation times, except at 1 and 3 min (Table 2). In this test, there was a significant difference $(p=0.0019)$ in the dry weight consumed, and the most heavily consumed cultivars were NA 7337 RR (3.95 mg), P 98Y 30 RR (3.62 mg), and NK 7059 RR (3.50 mg).

At 5 and $10 \mathrm{~min}(p=0.0002$ and 0.0017$)$, the greatest mean attractiveness was observed for the NK 7059 RR and BRS 8160 RR cultivars, which differed significantly from the other cultivars at both times. At $15 \mathrm{~min}$, in addition to the aforementioned two most attractive cultivars $(p=0.0068), \mathrm{M}$ 7110 IPRO was also among the most attractive cultivars.

At $30 \mathrm{~min}$, the NK $7059 \mathrm{RR}$ and M 7110 IPRO cultivars were the most attractive $(p=0.0007)$, with 0.4 and 0.3 larvae, respectively, per leaf disk. At 1 and $2 \mathrm{~h}$ after larval release, the NK 7059 RR, ANTA 82 RR, M 7110 IPRO, and BRS 8160 RR cultivars showed the largest means $(p=0.0273$ and 0.0009 , respectively), differing from the others.

At $6 \mathrm{~h}$, the NK 7059 RR, BRS 8160 RR, ANTA 82 RR, BRSGO Jataí, and NA 7337 RR cultivars were the most attractive. At $12 \mathrm{~h}, \mathrm{NK} 7059 \mathrm{RR}$ was the most attractive ( $p<$ 0.0001 ), obtaining a mean of one larva per leaf disk. The treatments with the smallest means were SYN 1163 RR, M 7110 IPRO, and IAC 100 (0.30, 0.20 and 0.15 , respectively). At $24 \mathrm{~h}$, the most attractive cultivars were P 98 Y30 RR, NA 7337 RR, SYN 1163 RR, NK 7059 RR, ANTA 82 RR, and IAC 100. The least attractive cultivars were M 7110 IPRO, BRS 8160, and BRSGO Jataí. Using their AIs, the NK 7059 RR cultivar was considered stimulatory and the others were considered deterrent to the feeding of $H$. virescens (Figure 2).

\section{Discussion}

In the free-choice test, a significant difference was observed after the 6-h evaluation, whereas the cultivars exhibited no differences at the first evaluation times. These results can be explained by the fact that the larvae fed on the artificial diet until the completion of the experiment, without undergoing a period of feeding interruption. Boiça Junior et al. (2015) assessed the types of resistance to Spodoptera cosmioides (Lepidoptera: Noctuidae). Souza et al. (2012) examined the feeding nonpreference of Spodoptera eridania (Lepidoptera: Noctuidae) in a free-choice test with soybean genotypes and also found significant differences only in the last times assessed.

Starting at $6 \mathrm{~h}$, the NK $7059 \mathrm{RR}$ cultivar was the most attractive to $H$. virescens, obtaining the largest mean number of larvae per leaf disk until the end of the experiment and suffering the heaviest consumption. The cultivar IAC 100 was one of the least attractive cultivars, presenting relatively few larvae per disk leaf and being the least heavily consumed.

The feeding preference of an herbivorous insect depends on plant stimuli, which can be positive or negative as well as chemical (Hoffmann-Campo et al., 2001), physical (Coelho et al., 2009), and/or morphological (Silva et al. 2012; Smith et al., 2014) in nature. Therefore, the $H$. virescens larvae received positive stimuli from the NK 7059 RR cultivar, which obtained the highest $\mathrm{AI}$ in the free-choice test.

In the no-choice test, differences were observed among the cultivars starting at $5 \mathrm{~min}$. NK $7059 \mathrm{RR}$ was the cultivar most attractive to the $H$. virescens larvae, obtaining the most larvae per leaf disk, on average, and a relatively high AI as well as suffering relatively high consumption.

Cultivar IAC 100 presented relatively small attractiveness means in the no-choice test, being repellent and appearing deterrent to $H$. virescens. According to Souza et al. (2012), Valle et al. (2012), Silva et al. (2013), Souza et al. (2014a), and Souza et al. (2014b), the IAC 100 cultivar was resistant to several species of phytophagous insects, serving as the basis for soybean genetic improvement programs aimed at incorporating insect resistance genes (McPherson and Buss, 2007).

The M 7110 IPRO $(B t)$ cultivar experienced the least consumption in the no-choice test and attained the lowest AI, being repellent to $H$. virescens. Bernardi et al. (2014) and Bortolotto et al. (2014) assessed the larval biology of $H$. virescens in genetically modified soybean plants $(B t)$ and concluded that the pest is highly susceptible, thereby suffering larval mortality. The lower consumption indexes in this cultivar are due to the presence of toxins from Bacillus thuringiensis (Eubacteriales: Bacillaceae), which induce the formation of endotoxins (Waquil et al., 2002) poisonous to insects, especially lepidopterans. These polypeptides bind to receptors on the microvilli of insect intestinal cells, causing osmotic lysis, which results in insect death (Schnepf et al., 1998; Bobrowski et al., 2003).

These soybean cultivars resistant to $H$. virescens can be used directly by soybean producers or in association with other control strategies for the management of this defoliating caterpillar.

\section{Materials and Methods}

\section{Experiment site}

The study was conducted at the Laboratory of Agricultural Entomology of the Federal Institute of Goiás (Instituto Federal Goiano), Urutaí Campus, Urutaí, Goiás State, Brazil, under controlled conditions $\left(25 \pm 2{ }^{\circ} \mathrm{C}, 70 \pm 10 \%\right.$ relative humidity, and a $12-\mathrm{h}$ photoperiod) in heated room.

\section{Rearing of $\boldsymbol{H}$. virescens}

$H$. virescens pupae, which developed from larvae donated by the Laboratory of Entomology EMBRAPA Rice and Beans, were sexed and placed in PVC cages (20-cm height $\mathrm{x} 20-\mathrm{cm}$ diameter), where adult emergence and mating occurred. The adults were fed a $10 \%$ honey solution placed in polyethylene terephthalate (PET) plates on a wad of cotton, which was replaced every two days. Eggs were removed daily and disinfected with 5\% sodium hypochlorite solution for five seconds, rinsed with distilled water, and placed in Petri dishes $(9.0 \times 1.5 \mathrm{~cm})$ with moistened filter paper until larval hatching. The hatched larvae were placed in groups of four within $150-\mathrm{mL}$ plastic pots containing artificial diet (Greene et al, 1976). On becoming third instars, the larvae were placed individually in plastic pots until the pupal stage to provide insects for the next cohort.

\section{Acquisition of plants and performance of tests}

Seeds of the soybean cultivars P 98 Y30 RR, NA 7337 RR, SYN 1163 RR, NK 7059 RR, ANTA 82 RR, M 7110 IPRO (Bt), BRS 8160 RR, BRSGO Jataí, and IAC 100 were sown in 5-L pots with a substrate composed of a 3:1 soil:organic compost mixture to obtain the leaves used in attractiveness and nonpreference tests.

\section{Attractiveness and non-preference for feeding}

Two laboratory tests with third-instar $H$. virescens larvae were started 45 days after the soybean seeds were sown. A 
free-choice attractiveness test was conducted by offering leaf disks of the different genotypes to the third-instar larvae. Leaves were collected from the plants and cut to provide 2.5$\mathrm{cm}$-diameter disks that were distributed circularly in test arenas (14-cm diameter $\mathrm{x} 2-\mathrm{cm}$ height) on moistened filter paper. Two symmetrically positioned leaf disks were cut from the leaves collected from each genotype; one disk was offered to a larva and the other, designated an aliquot, was dried in an oven at $60{ }^{\circ} \mathrm{C}$ for $48 \mathrm{~h}$. Subsequently, the dry weight consumed by the larva was determined by the weight difference between the dried aliquot and the dried leftovers from the offered leaf disk.

A no-choice attractiveness test was performed by offering the same genotypes individually. The leaves were collected and prepared as described for the previous test. One leaf disk per 6-cm-diameter Petri dish was placed on moistened filter paper. The dry weight consumed was determined using the previously described aliquot method.

In both tests, the attractiveness was evaluated at 1, 3, 5, 10, 15 , and $30 \mathrm{~min}$ as well as $1,2,6$, and $24 \mathrm{~h}$ after larval release by counting the number of insects attracted to the leaf disk of each genotype. For the free-choice attractiveness test, arranged in a randomized block design with 10 replications were performed. For the no-choice attractiveness test, a completely randomized design with 20 replications was adopted.

At the end of the tests, an attractiveness index (AI) was calculated according to Kogan and Goeden (1970) with the following formula: $\mathrm{AI}=2 \mathrm{C} /(\mathrm{C}+\mathrm{S})$, where $\mathrm{C}=$ the number of insects attracted to the evaluated genotype and $\mathrm{S}=$ the number of insects attracted to the standard susceptible genotype (BRS 8160 RR according to Souza et al., 2012). The AI values can vary between zero and two: $\mathrm{AI}=1,<1$, and $>1$ indicate similar, lesser and greater attractiveness, respectively, of the evaluated genotype compared with the standard susceptible genotype.

\section{Statistical analysis}

The data obtained in the tests were subjected to analysis of variance (ANOVA) and F-test, and the means were compared using the Scott-Knott test in Sisvar 5.3 (Ferreira, 2011). A probably level of $5 \%$ or less was considered statistically significant.

\section{Conclusion}

Cultivar NK 7059 RR was the most susceptible to $H$. virescens in the feeding nonpreference tests. Cultivars IAC 100 and M 7110 IPRO (Bt) showed nonpreference-type resistance to $H$. virescens. These latter cultivars can be used by soybean producers or plant breeders as donors of resistance genes in plant improvement programs for resistance to $H$. virescens.

\section{Acknowledgments}

The authors thank Instituto Federal Goiano - Campus Urutaí for funding the present study and the authors want to thank the Brazilian Council for Scientific and Technological Development - CNPq (Conselho Nacional de Desenvolvimento Científico e Tecnológico - CNPq) for productivity in research grant conseded for the last author.

\section{References}

Bernardi O, Dourado PM, Carvalho RA, Martinelli S, Berger GU, Head GP, Omoto C (2014) High levels of biological activity of Cry1Ac protein expressed on MON $87701 \mathrm{x}$ MON 89788 soybean against Heliothis virescens (Lepidoptera: Noctuidae). Pest Manag Sci. 70: 588-594.

Blanco CA, Gould F, Vega-Aquino P, Jurat-Fuentes JL, Perera OP, Abel CA (2009) Response of Heliothis virescens (Lepidoptera: Noctuidae) strains to Bacillus thuringiensis Cry1Ac incorporated into different insect artificial diets. J Econ Entomol. 102: 1599-1606.

Boiça Júnior AL, Bottega DB, Souza BHS, Rodrigues NEL, Michelim, V (2015) Determinação dos tipos de resistência a Spodoptera cosmioides (Wlker) (Lepdoptera: Noctuidae) em genótipos de soja. Semina 36: 607-618.

Bortolotto OC, Bueno AF, Braga K, Barbosa GC, Sanzovo A (2014) Biological characteristics of Heliothis virescens fed with Bt-soybean MON 87701 x MON 89788 and its conventional isoline. An Acad Bras Ciênc. 86: 973-980.

Bueno AF, Batistela MJ, Bueno RCOF, França-Neto JB, Nishikawa MAN, Libério Filho A (2011a) Effects of integrated pest management, biological control and prophylactic use of insecticides on the management and sustainability of soybean. Crop Protec. 30: 937-945.

Bueno A, Hirose E, Sosa-Gómez DR (2013) Manejo Racional. Cult Grand Cult. 173: 26-28.

Bueno RCOF, Bueno AF, Moscardi F, Parra JRP, HoffmanCampo CB (2011b) Lepidopteran larva consumption of soybean foliage: basis for developing multiple-species economic thresholds for pest management decisions. Pest Manag Sci. 67: 170-174.

Bueno RCOF, Parra JRP, Bueno AF (2012) Trichogramma pretiosum parasitism of Pseudoplusia includens and Anticarsia gemmatalis eggs at different temperatures. Biol Contrl. 60: 154-162.

Castanheira EG, Freire F (2013) Greenhouse gas assessment of soybean production: implications of land use change and different cultivation systems. J Clean Product. 54: 49-60.

Coelho SAMP, Lourenção AL, Melo AMT, Schammass EA (2009) Resistência de genótipos de meloeiro a Bemisia tabaci biótipo B. Bragantia. 68: 1025-1035.

Farrow RA, Daly JC (1987) Long-range movements as an adaptive strategy in the genus Heliothis (Lepidoptera: Noctuidae) a review of its occurrence and detection in four pest species. Austrl J Zool. 35: 1-24.

Ferreira DF (2011) Sisvar: a computer statistical analysis system. Ciênc Agrotecnol. 35: 1039-1042.

Fitt GP (1989) The ecology of Heliothis species in relation to agroecosystems. An Rev Entomol. 34: 14-52.

Greene GL, Leppla NC, Diekerson WA (1976) Velveatben caterpillar rearing produce and artificial medium. J Econ Entomol. 69: 487-488.

Hoffmann-Campo CB, Corrêa-Ferreira BS, Moscardi F (2012) Soja: manejo integrado de insetos e outros artrópodes praga. Embrapa. 859p.

Hoffmann-Campo CB, Harborne JB, Mccaffery AR (2001) Pre-ingestive and post-ingestive effects of soybean extracts and rutin on Trichoplusia ni growth. Ento Exper Appl. 98: 181-194.

Karpinski A, Haenniger S, Schofl G, Heckel DG, Groot AT (2014) Host plant specialization in the generalist moth Heliothis virescens and the role of egg imprinting. Evolut Ecol. 28: 1075-1093. 
Kogan M, Goeden RD (1970) The host-plant ranger of Lema trilineata daturaphila (Coleoptera: Chrysomelidae). Anl Entomol Scy Amerc. 63: 1175-1180.

Lourenção AL, Reco PC, Braga NR, Valle GE, Pinheiro JB (2010) Produtividade de genótipos de soja sob a infestação de lagarta-de-soja e de percevejos. Neotrop Entomol. 39: 275-281.

McPherson RM, Buss GR (2007) Evaluating lepidopteran defoliation resistance in soybean breeding lines containing the stink bug (Hemiptera: Pentatomidae) resistance IAC 100 cultivar in their pedigrees. J Econ Entomol. 100: 962968.

Owen LN, Catchol AL, Musser FR, Gore J, Cook DC, Jackson R, Allen C. (2013) Impact of defoliation on yield of group IV soybeans in Mississippi. Crop Protect. 54: 206212. Pratissoli D, Oliveira HN, Espindula MC, Magevski GC (2006) Ocorrência de lagarta-da-maçã-do-algodoeiro em frutos de tomateiro no estado do Espírito Santo. Hort Bras. 24: 204-205.

Seifi A, Visser RGF, Yuling BAI (2013) How to effectively deploy plant resistances to pests and pathogens in crop breeding. Euphytica.190: 321-334.

Silva JPGF, Baldin ELL, Canassa VF, Souza, E. S, Lourenção AL (2014) Assessing antixenosis of soybean entries against Piezodorus guildinii (Hemiptera: Pentatomidae) Arthropod-Plant Int. 8: 349-359.

Silva JPGF, Baldin ELL, Souza ES, Cassana VF, Lourenção AL (2013) Characterization of antibiosis to the redbanted stink bug Piezodorus guildinii (Hemiptera: Pentatomidae) in soybean entries. J Pest Sci. 86: 649-657.

Silva JPGF, Baldin ELL, Souza ES, Lourenção AL (2012) Assessing Bemisia tabaci (Genn.) biotype B resistance in soybean genotypes: antixenosis and antibiosis. Chil J Agric Res. 72: 516-522.

Smith, CM (2005) Plant resistance to arthropods: molecular and conventional approaches. Berlin, Springer. $423 \mathrm{p}$.

Sosa-Gomez DR, Silva JJ (2010) Neotropical brownstink bug (Euschistus heros) resistance to methamidophos in Paraná. Pesq Agropec Bras, 45: 767-769, 2010.

Souza BHS, Boiça Júnior AL, Janini JC, Silva AG, Rodrigues NEL (2012) Feeding of Spodoptera eridania (Lepdoptera: Noctuidae) on soybean genotypes. Rev Col Ento. 38: 215-223.
Souza PV, Machado BR, Freitas MM, Correa F, Almeida ACS, Jesus FG (2014a) Chrysodeixis includens (Lepdoptera: Noctuidae) soybean treated with resistance inducers. Afrc J Biotechnol.13: 4562-4567.

Souza PV, Machado BR, Silva DC, Menezes IPP, Araujo MS, Jesus FG (2014) Efect of resistance and trichome inducers on attraction of Euchistus heros (Hemiptera: Pentatomidae) to soybeans. Afr J Agric Res. 9: 889-894.

Tomquelski GV, Maruyama LCT (2009) Lagarta-da-maçã em soja. Rev Cult. 117: 20-22.

Valle GE, Lourenção AL, Pinheiro JB (2012) Adult atractiveness and oviposition preference of Bemisia tabacci biotype B in soybean genotypes with different trichome density. J Pest Sci. 85: 431-442.

Waquil JM, Villela FMF, Foster JE (2002) Resistência do milho (Zea mays L.) transgênico $(B t)$ à lagarta-do-cartucho, Spodoptera frugiperda (J.E. Smith) (Lepidoptera: Noctuidae). Rev Bras Mil Sorg. 1:. 2-11. 